\title{
Anti-proliferative Activity of Hibiscus sabdariffa L. Calyx Flavonoid Extracts on Cervical Cancer Cells using Flow Cytometry
}

\author{
Temilola Aina', Victor Akpe ${ }^{2,3}$, Olubunmi Magbagbeola', lan Edwin Cock ${ }^{2,3, *}$ \\ 'Department of Biochemistry, College of Medicine (Idi-Araba), University of Lagos, NIGERIA. \\ 'Environmental Futures Research Institute, Griffith University, Nathan Campus, QLD, AUSTRALIA. \\ ${ }^{3}$ School of Environment and Science, Griffith University, Nathan Campus, QLD, AUSTRALIA.
}

\begin{abstract}
Background: Impairment of the normal progression of the cell cycle affects the growth and development of the daughter cells, which may result in cancer cell proliferation. Herein, we investigate the effect of flavonoid fractions of Hibiscus sabdariffa L. calyx on cell cycle progression in cervical cancer cells. Methods: Flavonoids (bound and free), lipids and aqueous fractions were extracted from a methanolic extract of $H$. sabdariffa calyx using ethyl acetate, diethyl ether and petroleum ether. Each of these fractions were used to treat HeLa cervical cancer cells and monitored using a flow cytometer. Results: The cells exposed to the extract and its fractions had higher percentages of inactive cells (no cell division) at the quiescent $\left(G_{0}\right)$ and gap one phases $\left(G_{1}\right)$ of the cell cycle in comparison to control cells. The highest values were obtained from cells treated with the bound and free flavonoid fractions. Conclusion: The results of this study suggest that HeLa cervical cancer cell proliferation is significantly inhibited by $H$. sabdariffa flavonoid fractions. Daily consumption of beverages consisting
\end{abstract}

of $H$. sabdariffa may therefore prevent the early stages of cervical cancer and inhibit the progression of the disease once it is established.

Key words: Flavonoids, HeLa, Cervical cancer, Roselle, Flow cytometer, Cell cycle inhibition, Anti-proliferative extract.

\section{Correspondence:}

Dr. lan Edwin Cock

${ }^{2}$ Environmental Futures Research Institute, Griffith University, Nathan Campus, QLD 4111, AUSTRALIA.

${ }^{3}$ School of Environment and Science, Griffith University, Nathan Campus, QLD 4111, AUSTRALIA

Phone no: +61737357637

E-mail: i.cock@griffith.edu.au

DOI: $10.5530 /$ pc. 2021.2 .18

\section{INTRODUCTION}

Cervical cancer is caused by the cells in the linings in the cervix of women developing abnormalities. Squamous cell carcinoma is the most common form of the disease, accounting for approximately $70 \%$ of all cases. Adenocarcinomas are also relatively frequent but are more difficult to diagnose as they start higher in the cervix. Whilst there are many causes of cervical cancer, the most frequent etiology of this disease involves human papillomavirus (HPV) transmission from the carrier to the non-carrier during sexual activity. ${ }^{1}$ According to the World Health Organization (WHO, 2018), cervical cancer was recorded as the fourth largest cause of cancer among middle-aged women globally, mostly affecting women in under-resourced countries. ${ }^{2}$ In higher income countries, pap smear (cytology-based) testing remains the most widely used screening method for early detection among women. However, this method is relatively difficult to administer in low income countries due to the high costs required for clinical testing and treatment. ${ }^{3}$

Although several widely adopted practical alternatives including combinational visual effects using acetic acid and rapid human papillomavirus (HPV) detections have been beneficial in some lowincome countries, even these screening methods are relatively expensive to those populations and therefore their uptake remains limited. ${ }^{3}$ Consequently, the annual worldwide burden on cervical cancer is a triage beset by: (i) primary healthcare facilities; (ii) affordability and accessibilities to services; and (iii) perception and practises in different geographical locations. Notably, HPV vaccinations, which were launched for adolescent girls over a decade ago, ${ }^{4}$ have now been deployed to, and are routinely used in, approximately 100 countries (WHO, 2019). ${ }^{5}$ Despite the major milestones that have been achieved in the effective deployment of these vaccines, developing countries remain beset by high costs, difficulties with implementation, geographical isolation, as well as ethnic and socio-cultural issues. Due to these difficulties, it is estimated that more than $80 \%$ of women diagnosed with cervical cancer live in low- and middle-income countries. ${ }^{6}$
According to folklore medicine, therapeutic herbal plant treatments for diseases predate modern medicine by hundreds, or even thousands of years in some cultures. Furthermore, complementary and alternative medicine continues to attract attention, and indeed there has been a noteworthy increase in their uptake in some societies during the last decade. ${ }^{7}$ Some plants have been reported to have inherent anti-cancer properties, and often the toxicity levels have been suggested to be lower than in synthetic anti-cancer drugs. ${ }^{78}$ It is estimated that $80 \%$ of developing countries rely on the use of herbal plants to meet their primary health care needs. ${ }^{7}$ Additionally, the regular consumption of vegetables and fruits (particularly from high antioxidant plants) have been suggested to have prophylactic effects against many chronic diseases, including the prevention of certain cancer types. ${ }^{9}$

Hibiscus sabdariffa L. (Malvaceae) is an annual shrub widely cultivated as a food and beverage, for cosmetics, and for use in the health industry. ${ }^{10}$ Different parts of the plant including the leaves, seeds, stem and calyces are used as food, flavouring agent, and as a herbal beverage. ${ }^{11}$ Tea processed from the calyces is non-toxic and is regarded as relatively safe for consumption, even at high concentrations. ${ }^{12}$ Beverages sourced from the calyces of $H$. sabdariffa have been used effectively in traditional medicine for the treatment of numerous ailments and diseases, including the treatment of cough, abscesses, debility, dyspepsia, dysuria, fever, hangover, heart ailments, neurosis, scurvy, strangury, hypertension and cancer. ${ }^{13}$ Calyces of H. sabdariffa have been reported to contain phytochemicals that include alkaloids, anthocyanins, phenols, saponins, tannins and flavonoids. ${ }^{14,15}$ The active constituents of $H$. sabdariffa have been used for the treatment of some cancers and other diseases, ${ }^{14}$ particularly in the prevention of diseases associated with oxidative stress. Several studies have been published on the metabolic and hepatoprotective activities of the anthocyanin-rich calyces of $H$. sabdariffa examined in rats. ${ }^{16,17}$ However, the metabolic and hepatoprotective activities of isolated $H$. sabdariffa flavonoids, as well as 
crude extracts also containing other active components, remain to be rigorously examined at the cellular level. Interestingly, flavonoids abound in most plants, and the bioactivity of the some of these compounds have been identified to be beneficial to human health. ${ }^{17,18}$

Several epidemiological studies have indicated that the consumption of dietary flavonoids can suppress the onset and progression of some cancers. ${ }^{19}$ Case studies from Shanghai, Hawaii and Uruguay show that flavonoids reduce the incidence of esophagus, oral cavity, larynx and pharynx cancer by up to $70 \%$ in human subjects. ${ }^{18}$ In a different study, it was observed that the mortality rate of consumers of high levels of soy isoflavones was relatively low. ${ }^{17}$ Flavonoids can prevent cancer progression via the inhibition of several mechanisms, including invasion, metastasis, angiogenesis, apoptosis and cell cycle arrest. ${ }^{20}$ In this study, we determined the phytochemical constituents of crude extracts from the dried calyx of $H$. sabdariffa using quantitative and qualitative methods. ${ }^{21}$ We also determined the effect of lipid, aqueous, free and bound flavonoids fractions from the dried calyx of H. sabdariffa on the cell cycle of cervical cancer cell lines in vitro. ${ }^{22}$

\section{MATERIALS AND METHODS}

Labio Scientific Centre (Lagos, Nigeria) supplied the analytical grade petroleum ether, ethyl acetate, diethyl ether, methanol, dimethyl sulfoxide (DMSO) solvents used in this study. Jena Bioscience, Germany supplied the propidium iodide and ribonuclease (RNase). Sigma Aldrich (St. Louis, MO, USA) supplied the tissue culture grade penicillin/ streptomycin 100X solution, Eagle's minimum essential medium (EMEM), filter sterilised trypsin-EDTA solution 10X, ammonia solution, acetic anhydride, sulphuric acid chloroform, Folin-Ciocâlteu reagent (FCR), phenol, isobetyl alcohol, rutin, tannic acid and Folin-Denis' reagents. All reagents were analytical grade unless otherwise specified.

\section{Plant extraction process}

Dried calyces of $H$. sabdariffa were purchased from a local food store at a registered local market in Lagos, Nigeria. Authentication of the specimen was carried out at the Department of Botany, University of Lagos, Nigeria, with a voucher specimen (LUH No-6300) deposited in the herbarium.

\section{Preparation of methanolic extract of $H$. sabdariffa}

The H. sabdariffa calyces were air-dried in the shade for 21 days at room temperature. The air-dried calyces were ground to a coarse powder using a mesh size of $1 \mathrm{~mm}$. The ground material $(3.2 \mathrm{~kg})$ was soaked in $20 \mathrm{~L}$ methanol and allowed to stand at room temperature with continuous agitation for 5 days. The suspension was subsequently filtered through sterile muslin cloth and the filtrate was transferred to a rotary evaporator and concentrated at $3000 \mathrm{rev} / \mathrm{min}$ at $40^{\circ} \mathrm{C}$ to remove the solvent. The concentrate recovered from the rotary evaporator was completely dried (until there was no further change in mass following additional drying time) for $72 \mathrm{hr}$ at $40^{\circ} \mathrm{C}$ to ensure that all residual methanol was removed.

\section{Moisture content determination}

The moisture content of the extract was quantified using a Mettler Toledo moisture analyser. The initial weight of sample analysed was $0.831 \mathrm{~g}$ and the final weight was $0.82 \mathrm{~g}$. The total moisture content was determined to be $0.61 \%$.

\section{Fractionation of the $H$. sabdariffa extract}

The H. sabdariffa extract was fractionated by liquid partitioning in petroleum ether, diethyl ether and ethyl acetate following standard methods. ${ }^{23}$ Compounds were separated based on their differential solubility in a two-solvent system. A mass of $20 \mathrm{~g}$ of the solid extract was dissolved in $50 \mathrm{~mL}$ of distilled water in a beaker and transferred into a $500 \mathrm{~mL}$ separating funnel. A volume of $150 \mathrm{~mL}$ petroleum ether was added into the funnel to remove the extract and the resulting immiscible mixture was shaken vigorously and allowed to stand for 30 min. The mixture was subsequently separated into aqueous and organic layers and the two layers were collected separately. The aqueous layer was re-extracted twice with $150 \mathrm{~mL}$ petroleum ether to ensure complete removal of the lipid components. The aqueous layers were pooled together for further fractionation, while the organic layers containing the lipid components were evaporated to dryness at $50^{\circ} \mathrm{C}$. The aqueous layer was further partitioned using diethyl ether to remove the free flavonoids, or with ethyl acetate to fractionate the bound flavonoids. The organic fractions were evaporated to dryness separately at $50^{\circ} \mathrm{C}$ and weighed to determine the yield of extract. The dried ethyl acetate fraction was hydrolyzed with $7 \%(\mathrm{v} / \mathrm{v}) \mathrm{H}_{2} \mathrm{SO}_{4}$ for $24 \mathrm{hr}$, filtered, and re-extracted thrice with ethyl acetate. The ethyl acetate layers were neutralized by washing with distilled water and subsequently re-dried at $50^{\circ} \mathrm{C} .{ }^{24}$ The extracts were subsequently resuspended in deionised water for biological screening.

\section{Qualitative phytochemical screening}

Chemical tests were carried out on crude extracts (dried and resuspended in sterile deionised water) following standard procedures to identify phytochemical constituents. ${ }^{22}$ Briefly:

(1) Tannins; $0.5 \mathrm{~g}$ of the extract was dissolved in $20 \mathrm{~mL}$ of distilled water in a test tube. A few drops of $0.1 \%$ ferric chloride were added and checked for the development of a brownish green or a blue-black colouration.

(2) Phlobatannins; The plant extract was boiled in $1 \%$ hydrochloric acid and a deposition of a red precipitate was taken as an evidence for the presence of phlobatannins.

(3) Alkaloids; A mass of $2.5 \mathrm{~g}$ of the ethanolic extract was evaporated to dryness and the residue was heated in a boiling water bath with $10 \%$ $(\mathrm{v} / \mathrm{v}) \mathrm{HCl}(5 \mathrm{~mL})$. After cooling, the mixture was filtered, and the filtrate was divided into two equal portions. One portion was treated with a few drops of Mayer's reagent. ${ }^{25}$ The samples were then observed for the presence of cream precipitate.

(4) Saponins; A mass of $0.5 \mathrm{~g}$ of plant extract was dissolved in $20 \mathrm{~mL}$ of distilled water in a test tube and shaken vigorously to form a stable froth. The froth was mixed with three drops of olive oil and then shaken vigorously. The formation of an emulsion signifies the presence of saponin.

(5) Flavonoids; The extract was heated with $1 \mathrm{~mL}$ of dilute ammonia solution. A yellow coloration indicated the presence of flavonoids.

(6) Steroids; A $2 \mathrm{~mL}$ volume of acetic anhydride was added to $0.5 \mathrm{~g}$ of extract in $2 \mathrm{~mL}$ concentrated $\mathrm{H}_{2} \mathrm{SO}_{4}$. A colour change from violet to blue or green indicates the presence of steroids.

(7) Terpenoids (Salkowski test); ; $^{22}$ The plant extract $(2 \mathrm{~mL})$ was mixed with $2 \mathrm{~mL}$ of chloroform and $3 \mathrm{~mL}$ of concentrated $\mathrm{H}_{2} \mathrm{SO}_{4}$ was carefully added to form a layer. A reddish-brown coloration at the interface indicated the presence of terpenoids.

(8) Cardiac glycosides; A mass of $0.5 \mathrm{~g}$ of the plant extract was treated with $2 \mathrm{~mL}$ of glacial acetic acid containing one drop of ferric chloride solution. This was overlayed with $1 \mathrm{~mL}$ of concentrated sulphuric acid. A brown ring at the interface identifies the deoxy-sugar characteristics of cardiac glycosides. A violet ring may also appear below the brown ring while in the acetic layer.

(9) Reducing sugars; A $0.5 \mathrm{~mL}$ volume of plant extract was mixed with 5 to 8 drops of Fehling's solution and boiled for 2 min. ${ }^{26} \mathrm{~A}$ brick red precipitate indicates the presence of reducing sugar. 


\section{Quantitative phytochemical screening}

Quantitative analysis of the extract of $H$. sabdariffa calyx were performed to confirm the presence of some active constituents, employing standard conventional protocols. ${ }^{27}$

(1) Total phenolic content; The amount of phenol in the aqueous extract was quantified using the Folin-Ciocalteu method with some modifications. A volume of $2.5 \mathrm{~mL}$ of $10 \%$ Folin-Ciocalteu reagent and $2 \mathrm{~mL}$ of $2 \% \mathrm{Na}_{2} \mathrm{CO}_{3}$ solution was added to $1 \mathrm{~mL}$ of plant extract. The resulting mixtures were incubated for $15 \mathrm{~min}$ at room temperature. The absorbance of the sample was measured at $765 \mathrm{~nm}$. Tannic acid was used as a standard in the quantification of phenols as reported previously. ${ }^{28}$

(2) Total flavonoid content; A modified standard colorimetric method using aluminium chloride was used to determine the flavonoid content of the extract. A $1 \mathrm{~mL}$ of sample plant extract was mixed with $3 \mathrm{~mL}$ of methanol. Subsequently, $0.2 \mathrm{~mL}$ of $10 \%$ aluminium chloride, $0.2 \mathrm{~mL}$ of $1 \mathrm{M}$ potassium acetate and $5.6 \mathrm{~mL}$ of distilled water were added and allowed to stand at room temperature for $30 \mathrm{~min}$. The absorbance was measured at $420 \mathrm{~nm}$ using a Camspec M106 spectrophotometer against quercetin standard. ${ }^{29}$

(3) Alkaloid content; Alkaline precipitation was quantified using standard gravimetric methods. ${ }^{30} \mathrm{~A}$ mass of $1 \mathrm{~g}$ of the extract was dispersed into a solution of $10 \%$ acetic acid in ethanol in a ratio of 1:10 (10\%). The mixture was allowed to stand for $4 \mathrm{hr}$ and then filtered. The filtrate was evaporated to one quarter of its original volume and treated dropwise with the addition of concentrated aqueous $\mathrm{NH}_{4} \mathrm{OH}$ until the alkaloid precipitated. The precipitated alkaloid was filtered in a weighted filter paper, washed with $1 \%$ ammonia solution, and dried in the oven at $800^{\circ} \mathrm{C}$. The alkaloid content was calculated and expressed as percentage of the weight of sample analyzed.

(4) Tannin content; A mass of $0.2 \mathrm{~g}$ of the extract was weighed and added to $20 \mathrm{~mL}$ of $50 \%$ methanol. The mixture was covered with paraffin and placed in a water bath at $77-80^{\circ} \mathrm{C}$ for $1 \mathrm{hr}$ and stirred with a glass rod to prevent clumping. The extract was filtered through two layers of Whatman No.1 filter paper rinsed with $50 \%$ methanol and made up to the $100 \mathrm{~mL}$ mark with distilled water. A $1 \mathrm{~mL}$ volume of the resulting sample extract, $20 \mathrm{~mL}$ distilled water, $2.5 \mathrm{~mL}$ Folin-Denis reagent and $10 \mathrm{~mL}$ of $17 \% \mathrm{Na}_{2} \mathrm{CO}_{3}$ were added and mixed thoroughly. The mixture was made up to $50 \mathrm{~mL}$ mark with distilled water and allowed to stand at room temperature for $20 \mathrm{~min}$. A bluish-green coloration indicates the presence of tannins. The absorbance was measured and compared with a standard curve of standard tannic acid solution using a Camspec M106 spectrophotometer at a wavelength of $760 \mathrm{~nm} .^{31}$

(5) Saponin content; A volume of $100 \mathrm{~mL}$ isobutyl alcohol was added to $1 \mathrm{~g}$ of the extract. The mixture was filtered through a Whatman No.1 filter paper and $20 \mathrm{~mL}$ of $40 \%$ saturated solution of magnesium carbonate was added. The resulting mixture was filtered using Whatman No 1 filter paper to obtain a clear, colorless solution. A volume of 1 $\mathrm{mL}$ of the colorless solution was pipetted into $50 \mathrm{~mL}$ volumetric flask and $2 \mathrm{~mL}$ of $5 \% \mathrm{FeCl}_{3}$ solution was added and made up to $50 \mathrm{~mL}$ with distilled water. The solution was allowed to stand for $30 \mathrm{~min}$. A blood red coloration indicated presence of saponins. The absorbance was read and compared to a saponin standard solution ${ }^{32}$ using a Camspec M106 spectrophotometer at a wavelength of $380 \mathrm{~nm}$.

\section{Preparation of fractions for cell culture medium}

Stock solutions of each fraction (lipid fraction, free flavonoid fraction, bound flavonoid fraction and aqueous fraction) were prepared by dissolving $0.2 \mathrm{~g}$ of each fraction in $1 \mathrm{~mL}$ of dimethyl sulphoxide (10 $\%$ DMSO). The mixture was stirred in a crucible until a fine paste was obtained and made up to $10 \mathrm{~mL}$ with PBS (phosphate buffer saline).
The resulting solution was used to prepare the culture medium with a concentration of $200 \mu \mathrm{g} / \mathrm{mL} .^{33}$

\section{Cell culture methods}

Cervical cancer cell lines (HeLa cells) obtained from the American Type Culture Collection (ATCC; USA) and were used for the cellular assays. The cells were cultured in Eagle's minimum essential medium (EMEM) supplemented with $10 \%$ fetal bovine serum (FBS), 1\% penicillin/ streptomycin solution and maintained in an incubator with a humified atmosphere at a temperature of $37^{\circ} \mathrm{C}$ and $5 \% \mathrm{CO}_{2}$. The medium was aspirated when the cells reached $70 \%-80 \%$ confluence. Subsequently, the cells were seeded into a six well plate. A concentration of $200 \mu \mathrm{g} / \mathrm{mL}$ of each flavonoid fraction previously prepared from the stock solution (section 2.7) was added to the cultured cells in the plate wells, along with $5 \mathrm{~mL}$ of fresh culture medium. The cells were incubated for $24 \mathrm{hr}$ at $37^{\circ} \mathrm{C}$. The media was subsequently aspirated, the cells were harvested by washing twice with cold PBS to remove residual medium, and then trypsinized by adding $1.5 \mathrm{~mL}$ trypsin and centrifuged at $200 \mathrm{~g}$ for $5 \mathrm{~min}$. The supernatant was removed, leaving the cell pellet. ${ }^{34}$

\section{Flow cytometry analysis}

The cell pellet was fixed with $70 \%(\mathrm{v} / \mathrm{v})$ ethanol for $20 \mathrm{~min}$ and chilled at $4^{\circ} \mathrm{C}$ for $20 \mathrm{~min}$. The cells were then centrifuged at $200 \mathrm{~g}$ for $5 \mathrm{~min}$ and the ethanol supernatant discarded. The pellets were then re-suspended in $500 \mu \mathrm{L}$ of reagent buffer. Subsequently, $500 \mu \mathrm{L}$ of ribonuclease at a final concentration of $200 \mu \mathrm{g} / \mathrm{mL}$ was added to the cells and incubated for $30 \mathrm{~min}$. Propidium iodide $(100 \mu \mathrm{g} / \mathrm{mL})$ was added to the cells and the resulting mixture was incubated for $30 \mathrm{~min}$ at room temperature in the dark. ${ }^{34}$ The propidium iodide-stained cells were analyzed with a PARTEC flow cytometer using the FL3 channel and the cell cycle analysis of the data obtained was performed with Flowmax software to obtain the percentage of cells in $G_{0} / G_{1}, S$ phase and $G_{2} / M$ phases of the cell cycle using previously reported methods. ${ }^{34}$

\section{Statistical analysis}

Data are expressed as the mean \pm SEM of repeated experiments and one-way ANOVA was used to calculate statistical significance between control and treated groups ( $p<0.01$ deemed to be statistically significant).

\section{RESULTS AND DISCUSSION}

The cell cycle refers to the sequence of events by which a cell duplicates its DNA, synthesizes other cellular constituents, and eventually divides into two daughter cells. This sequence of events is: (1) the mitotic (M) phase, (2) gap 1 phase $\left(G_{1}\right)$, (3) gap 2 phase $\left(G_{2}\right)$, and (4) the synthesis phase $(S)$. Some cells may also undergo the quiescent $\left(G_{0}\right)$ phase where they do not divide but are metabolically active. Several studies have suggested that inducing cell cycle arrest at any of the major phases may prevent proliferation of cancer cells. ${ }^{35}$

Several scientific discoveries on the medicinal nature of plants have attributed the prevention and treatment of chronic diseases to the phytochemical compounds present in plants. Hibiscus sabdariffa is an example of plant known for its beneficial role in the treatment and prevention of some diseases. ${ }^{36}$ In the present study, phytochemical analysis of the methanolic extract of the calyx revealed the presence of flavonoids, tannins, phlobatannins, alkaloids, phytosterols, polyphenolics, cardiac glycosides and terpenoids. Table 1 shows the result of the qualitative and quantitative analyses. The results are consistent with previous studies ${ }^{37,38}$ that also reported the presence of these phytochemical classes in the methanolic extract of the calyx.

Quantitative screening of the methanolic extract (Table 1) of the calyx of $H$ sabdariffa showed that the major phytochemical components are 
flavonoids, alkaloids, tannins, and phenols, in decreasing order of relative abundance, respectively. This analysis agrees with the work of Nkumah ${ }^{15}$ which showed that $H$. sabdariffa is rich in flavonoids. Similarly, Alaga et al..$^{39}$ also reported that flavonoid is the most abundant phytochemical class in ethanolic extracts of $H$. sabdariffa calyx.

Previous research work has revealed the anticancer properties of flavonoids, with diverse mechanisms of action, including inhibition of cell growth and proliferation by arresting the cell cycle, induction of apoptosis and differentiation, or a combination of these mechanisms as suggested by Raffa et al. ${ }^{40}$ Notably, flavonoids including quercetin induce cell cycle arrest at $G_{1} / S$ or $G_{2} / M$ phase in multiple cancer cell lines, including some cervical cancer cell lines. ${ }^{41}$

Consequently, we tested the cell cycle inhibitory effect of the lipid, bound flavonoids, free flavonoids, and aqueous fractions that were obtained from the methanolic $H$. sabdariffa calyx extract. Each of these fractions were screened to investigate the effect of flavonoid components on the cell cycle of HeLa cervical cancer cells. Analysis of the cell cycle phases using the FL3 channel on flow cytometry revealed a higher percentage of cells at the $G_{0} / G_{1}$ phase interface, and a lower percentage of cells in the $S$ phase, or in the $G_{2} / M$ phases when the cells were exposed to the bound flavonoid fraction, compared with the untreated control cells (Figure 1A and $1 \mathrm{~B}$ ). The effects of the free flavonoid, lipid and aqueous fractions on cell cycle distribution of HeLa cells are reported in Figures 1C, 1D and $1 \mathrm{E}$ respectively. The result from each of the responses after $24 \mathrm{~h}$ exposure suggests that the flavonoid containing extracts suppress cell proliferation by inducing cell cycle arrest at the $G_{0} / G_{1}$ phase. This is in accordance with the work of Tavsan and Kayali ${ }^{42}$ and Song et al. ${ }^{43}$ who both reported that flavonoids induce cell cycle arrest at $G_{0} / G_{1}$ phase. Indeed, luteolin induces cell cycle arrest at the $G_{0} / G_{1}$ interface in colon cancer cells, ${ }^{42}$ while the flavonoid extract (casticin) from Vitex rotundifolia L induces cell cycle arrest at $G_{0} / G_{1}$ phase in gall bladder cancer. ${ }^{43}$ It is likely that the H. sabdariffa flavonoid components contribute to the cell cycle arrest reported in our study, although this remains to be verified.

Numerous studies have been published examining the mechanism of action of flavonoids in regulating the cell cycle of cervical cancer cells. Cyclin dependent kinases (CDKs) and cyclins, which represents a family of cell progression proteins, play a significant role in the cell cycle regulation. ${ }^{44}$ Different cyclins and CDKs regulate cell progression through each phase of the cell cycle. Of particular interest, CDK2, CDK4, and cyclin $\mathrm{D}$ are important regulators of $\mathrm{G}_{0} / \mathrm{G}_{1}$ phase progression. ${ }^{45}$
At the end of $\mathrm{G}_{1}$ phase, CDK4 is activated by dephosphorylation of its threonine 172 residue, which enables it to bind with cyclin D, with CDK 6 activated by binding to cyclin D. ${ }^{46}$ Formation of either cyclin D-CDK 4 complex or cyclin D-CDK6 complex is important for the transition from the $\mathrm{G}_{1}$ phase to the $\mathrm{S}$ phase of the cell cycle. ${ }^{46}$ It was also observed that the activation of cyclin-CDK complex (cyclin D-CDK6 and cyclin D-CDK4) can be inactivated by binding to cyclin dependent kinase inhibitors (CDI) that are specific to the $\mathrm{G}_{1}$ phase of the cell cycle. Two types of CDI associated with $G_{1}$ phase are the CIP/KIP family, which includes $\mathrm{p} 21^{\mathrm{cip} 1}, \mathrm{p} 27^{\mathrm{Kip} 1}, \mathrm{p} 57^{\mathrm{Kip} 2}$ and the INK4 family (which includes $\mathrm{p} 15^{\mathrm{INK} 4 \mathrm{a}}, \mathrm{p} 16^{\mathrm{INK} 4 \mathrm{~b}}, \mathrm{p} 18^{\mathrm{INK} 4 \mathrm{c}}$ and $\left.\mathrm{p} 19^{\mathrm{INK} 4 \mathrm{~d}}\right)$. Binding of any of these CDIs to the activated cyclin-CDK complex would inactivate it, thereby stopping cell cycle progression from the G1 to S phase. ${ }^{47}$

Given the results from this study, we deduced that the inhibition of a cell

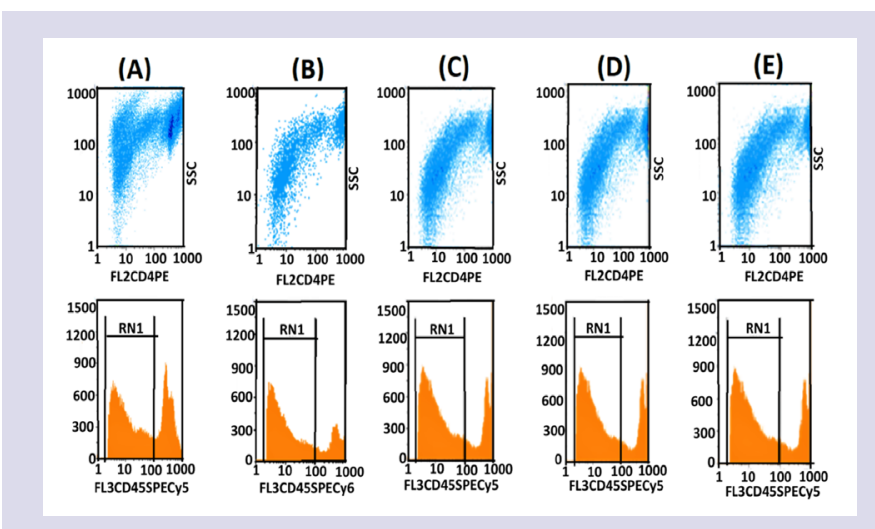

Figure 1: Flow cytometry analysis of the cell cycle distribution in HeLa cells at $200 \mu \mathrm{g} / \mathrm{mL}$ for $24 \mathrm{~h}$. In the control, the cells were incubated without any dose of the prepared fractions (A) Control for the $\mathrm{G}_{0} / \mathrm{G}_{1}=41.00$ $\pm 1.00 \%$; $S$ phase $=15.00 \pm 1.00 \% ; G_{2} / M=43.33 \pm 1.16 \%$. (B) Bound flavonoid fraction: $\mathrm{G}_{0} / \mathrm{G}_{1}=73.33 \pm 2.08 \% ; \mathrm{S}$ phase $=21.00 \pm 2.00 \% ; \mathrm{G}_{2} / \mathrm{M}=$ $23.67 \pm 3.22 \%$ (C) Lipid fraction: $\mathrm{G}_{0} / \mathrm{G}_{1}=48.33 \pm 1.53 \%$; $\mathrm{S}$ phase $=12.67$ $\pm 0.58 \%$ and $G_{2} / M=39.00 \pm 2.00 \%$ (D) Free flavonoid fraction: $G_{0} / G_{1}=$ $80.67 \pm 2.08 \% ; S$ phase $=19.00 \pm 3.60 \% ; G_{2} / M=8.33 \pm 2.08 \%$ (E) Aqueous fraction: $G_{0} / G_{1}=65.67 \pm 4.07 \% ; S$ phase $=16.00 \pm 3.61 \% ; G_{2} / M=$ $8.33 \pm 1.53 \%$. The side-scattered light (SSC) is proportional to the cell granularity and measures the HeLa cells' physical properties in the flow cytometry.

Table 1: Phytochemical constituents of the crude methanolic extract of Hibiscus sabdariffa calyx.

\begin{tabular}{cccccc}
\hline Observed(N) & Test & Aqueous extract & Fractions & Absorbance & Yield $(\mu \mathrm{g} / \mathrm{g})$ \\
\hline 1 & Tannins & + & 0.10 & $2.15 \pm 0.00$ \\
2 & Phlobatannins & + & & \\
3 & Alkaloids & + & 0.77 & $3.86 \pm 0.05$ \\
4 & Steroids & + & & \\
5 & Flavonoids & + & 0.03 & $6.56 \pm 1.01$ \\
6 & Phenols & + & 0.003 & $1.66 \pm 0.01$ \\
7 & Cardiac & + & & \\
8 & glycosides & & & \\
9 & Terpenoids & + & & \\
10 & Saponin & - & & \\
& Reducing sugars & + & & \\
\hline
\end{tabular}

Values are means of triplicate determination $(n=3) \pm$ standard deviation (SD); + indicates that the component was present; - indicates that the component was absent 


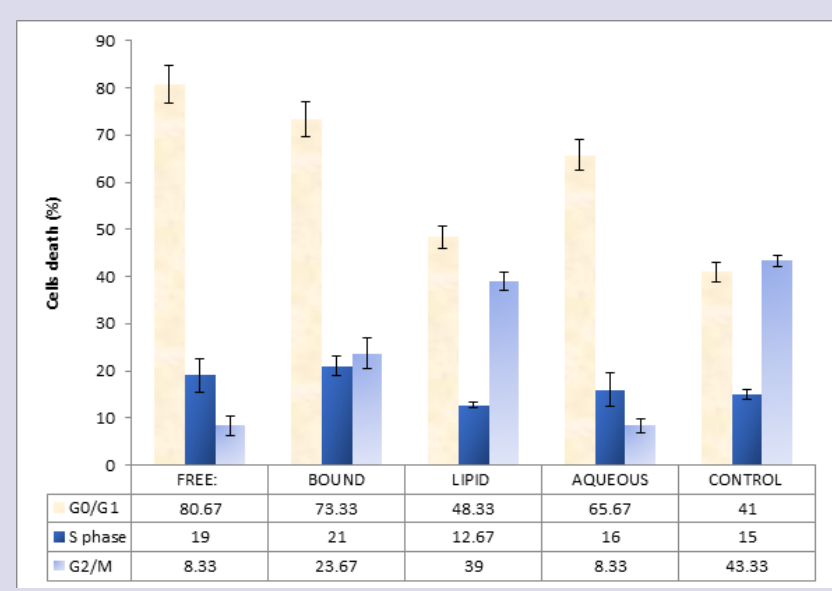

Figure 2: Analysis of the cell cycle distribution of HeLa cells. Values are expressed as the percentage of the cell population in the $G_{0} / G_{1}, S$, and $\mathrm{G}_{2} / \mathrm{M}$ phase of cell cycle. Cells were treated with the extract fractions $(200 \mu \mathrm{g} / \mathrm{mL}$ ), except for the deionised water control. They were incubated for $24 \mathrm{hr}$. Each value represents the mean of three experiments; bars \pm SD $(P<0.05$ was considered significant)

cycle arrest by the flavonoid containing fractions at $\mathrm{G}_{0} / \mathrm{G}_{1}$ phase may be due to their ability to down regulate cyclin D, CDK4 and/or CDK6 protein, although this is yet to be verified. Furthermore, the progression from the $G_{1}$ phase to the $S$ phase of the cell cycle may be attributed to the inactivation of the activated cyclin D-CDK4 and cyclin D-CDK6 complexes by CDIs in those fractions. Such inactivation can also prevent cell progression from the $G_{1}$ phase to the $S$ phase of the cell cycle. ${ }^{47}$

Whilst the four fractions were able to induce cell cycle arrest at the $G_{0} / G_{1}$ phase, exposure to the bound and free flavonoid H. sabdariffa fractions induced a substantially higher percentage of cells to remain in the $G_{0}$ phase compared to untreated control cells (Figures 1). A quantification of the responses of each of the $H$. sabdariffa fractions (as well as the control cells) on HeLa cells is shown in Figure 2. Notably, the flavonoid containing fractions were substantially more effective in inducing cell cycle arrest in HeLa cells, thereby inhibiting the proliferation of this cervical cancer cell line.

\section{CONCLUSION}

This study demonstrates that bound and free flavonoid containing fractions prepared from a methanolic $H$ sabdariffa extract were effective in preventing proliferation of cervical cancer cells by inducing cell cycle arrest at the $G_{0} / G_{1}$ phase. Whilst the phytochemical composition of these fractions was not comprehensively evaluated, it is likely that their flavonoid components may contribute (at least in part) to the cell cycle inhibitory activity reported herein. However, our phytochemical evaluation studies also revealed a relative abundance of alkaloids, tannins and other polyphenols in these extracts and these are likely to also contribute to the bioactivities reported herein. Further studies to identify and determine the contribution of all components is required. However, from the results of our study, it is likely that regular consumption of beverages made from the calyx of $H$. sabdariffa may be effective in preventing the proliferation of cervical cancer cells, although this is yet to be verified in vivo. It is anticipated that these findings enhance awareness of relevant health and food regulatory agencies on the consumption of beverages made from the calyx of Hibiscus sabdariffa. Furthermore, it is hoped that this study will highlight the benefits of this important species and focus further studies in this field.

\section{ACKNOWLEDGEMENT}

L.A. acknowledges the College of Medicine, Idi-Araba, and University of Lagos for support towards this research. We are grateful to PZ Cussons, Lagos Nigeria for the use of the Mettler Toledo moisture analyser.

\section{ABBREVIATIONS}

CDKs: Cyclin dependent kinases; CDI: cyclin dependent kinase inhibitors (CDI); KIP: kinase inhibiting protein; $\mathbf{M}$ : mitotic phase; $\mathbf{G}_{\mathbf{1}}$ : gap 1 phase; $\mathbf{G}_{2}$ : Gap 2 phase, $\mathbf{S}$ : synthesis phase; $\mathbf{G}_{0}$ : Quiescent phase; HPV: human papillomavirus; FCR: Folin-Ciocâlteu reagent; WHO: world health organization; ATCC: American Type Culture Collection; EMEM: Eagle's minimum essential medium; FBS: fetal bovine serum; PBS: phosphate buffer saline; DMSO: dimethyl sulphoxide.

\section{REFERENCES}

1. Baldwin SB, Wallace DR, Papenfuss MR, et al. Human papillomavirus infection in men attending a sexually transmitted disease clinic. The Journal of Infectious Diseases. 2003;187(7):1064-70

2. Arbyn M, Weiderpass $E$, Bruni $L$, et al. Estimates of incidence and mortality of cervical cancer in 2018: A worldwide analysis. The Lancet Global Health. 2020;8(2):e191-203

3. Sahasrabuddhe W, Parham GP, Mwanahamuntu MH, et al. Cervical cancer prevention in low-and middle-income countries: Feasible, affordable, essential. Cancer Prevention Research. 2012;5(1):11-7.

4. Bonanni $P$, Bechini $A$, Donato $R$, et al. Human papilloma virus vaccination: Impact and recommendations across the world. Therapeutic Advances in Vaccines. 2015;3(1):3-12.

5. WHO. (https://www.who.int/news-room/detail/31-10-2019-major-milestonereached-as-100-countries-have-introduced-hpv-vaccine-into-national-schedule). cited 28 Dec 2020

6. Foss HS, Oldervoll A, Fretheim A, et al. Communication around HPV vaccination for adolescents in low-and middle-income countries: A systematic scoping overview of systematic reviews. Systematic Reviews. 2019;8(1):1-5. Article number 190.

7. Sawadogo WR, Schumacher M, Teiten M-H, et al. Traditional West African pharmacopeia, plants and derived compounds for cancer therapy. Biochemical Pharmacology. 2012;84(10):1225-40.

8. Buyel J. Plants as sources of natural and recombinant anti-cancer agents. Biotechnology Advances. 2018;36(2):506-20.

9. Banikazemi Z, Haji HA, Mohammadi M, et al. Diet and cancer prevention: Dietary compounds, dietary MicroRNAs, and dietary exosomes. Journal of Cellular Biochemistry. 2018;119(1):185-96.

10. Villani T, Juliani HR, Simon JE, et al. Hibiscus sabdariffa: phytochemistry, quality control, and health properties. In: African Natural Plant Products Volume II: Discoveries and Challenges in Chemistry, Health and Nutrition. ACS Publications. 2013;209-30.

11. Meraiyebu A, Olaniyan $\mathrm{O}$, Eneze $\mathrm{C}$, et al. Anti-inflammatory activity of methanolic extract of Hibiscus sabdariffa on carrageenan induced inflammation in wistar rat. International Journal of Pharmaceutical Science Invention. 2013;2(3):22-4.

12. Lu B, Li M, Yin R. Phytochemical content, health benefits and toxicology of common edible flowers: A review (2000-2015). Critical Reviews in Food Science and Nutritio. 2016;56(sup1):S130-48.

13. Obouayeba A, Djyh N, Diabate S, et al. Phytochemical and antioxidant activity of Roselle (Hibiscus sabdariffa L.) petal extracts. Research Journal of Pharmaceutical, Biological and Chemical Sciences. 2014;5(2):1453-65.

14. Da-Costa-Rocha I, Bonnlaender B, Sievers $H$, et al. Hibiscus sabdariffa L. A phytochemical and pharmacological review. Food Chemistry. 2014;165:424-43.

15. Nkumah OC, et al. Phytochemical analysis and medicinal uses of Hibiscus sabdariffa. International Journal of Herbal Medicine. 2015;2(6):16-9.

16. Ezzat SM, Salama MM, Seif el-Din SH, et al. Metabolic profile and hepatoprotective activity of the anthocyanin-rich extract of Hibiscus sabdariffa calyces. Pharmaceutical Biology. 2016;54(12):3172-81.

17. Wang CJ, Wang JM, Lin WL, et al. Protective effect of Hibiscus anthocyanins against tert-butyl hydroperoxide-induced hepatic toxicity in rats. Food and Chemical Toxicology. 2000;38(5):411-6.

18. Chahar MK, Sharma N, Dobhal MP, et al. Flavonoids: A versatile source of anticancer drugs. Pharmacognosy Reviews. 2011;5(9):1-12.

19. Veeramuthu D, Raja WRT, Al-Dhabi NA, et al. Flavonoids: Anticancer properties. In Flavonoids: From Biosynthesis to Human Health. 2017;287. DOI: 10.5772/68095

20. Amawi H, Ashby CR, Tiwari AK. Cancer chemoprevention through dietary flavonoids: What's limiting?. Chinese Journal of Cancer. 2017;36(1):1-13. 
21. George VC, Dellaire G, Rupasinghe HV. Plant flavonoids in cancer chemoprevention: Role in genome stability. The Journal of Nutritional Biochemistry. 2017;45:1-14.

22. Edeoga HO, Okwu D, Mbaebie B. Phytochemical constituents of some Nigerian medicinal plants. African Journal of Biotechnology. 2005;4(7):685-8.

23. Subramanian SS, Nagarajan S. Flavonoids of seeds of Crotolaria retusa and $C$. straita. Current Science. 1969;38 365.

24. Yadav S, Kumar P. Production, isolation and identification of flavonoids from aerial parts of Hiptage benghalensis. Int J Life Sci Pharma Res. 2012;2(3):1-5.

25. Yadav RN, Agarwala M. Phytochemical analysis of some medicinal plants. Journal of Phytology. 2011;3(12):10-4

26. Mohan C, Dinakar S, Anand T, Elayaraja R, Sathiya PB. Phytochemical, GC-MS analysis and antibacterial activity of a medicinal plant Acalypha indica. Int J Pharm Tech Res. 2012;4(3):1050-4.

27. Evans WC. Trease and Evans' pharmacognosy E-book. Elsevier Health Sciences. 2009.

28. Blainski A, Lopes GC, DeMello JCP. Application and analysis of the Folin Ciocalteu method for the determination of the total phenolic content from Limonium brasiliense L. Molecules. 2013;18(6):6852-65.

29. Kalita P, Tapan BK, Pal TK, Kalita R. Estimation of total flavonoids content (TFC) and anti-oxidant activities of methanolic whole plant extract of Biophytum sensitivum Linn. Journal of Drug Delivery and Therapeutics. 2013;3(4):33-7.

30. Box JD. Investigation of the Folin-Ciocalteau phenol reagent for the determination of polyphenolic substances in natural waters. Water Research. 1983;17(5):511-25.

31. Adeniyi SA, Orjiekwe CL, Ehiagbonare JE. Determination of alkaloids and oxalates in some selected food samples in Nigeria. African Journal of Biotechnology. 2009;8(1):110-2.

32. Uematsu Y, Hirata K, Saito K, Kudo I. Spectrophotometric determination of saponin in Yucca extract used as food additive. Journal of AOAC International. 2000;83(6):1451-4

33. Ramesh E, Alshatwi AA. Naringin induces death receptor and mitochondriamediated apoptosis in human cervical cancer ( $\mathrm{SiHa}$ ) cells. Food and Chemical Toxicology. 2013;51:97-105.

34. Park KI, Park HS, Nagappan A, et al. Induction of the cell cycle arrest and apoptosis by flavonoids isolated from Korean Citrus aurantium L. in non-small-cell lung cancer cells. Food Chemistry. 2012;135(4):2728-35.

35. Ingham M, Schwartz GK. Cell-cycle therapeutics come of age. Journal of Clini- cal Oncology. 2017;35(25):2949-59.

36. Obouayeba AP, Djyh NB, Diabate S, et al. Phytochemical and antioxidant activity of Roselle (Hibiscus sabdariffa L.) petal extracts. Research Journal of Pharmaceutical, Biological and Chemical Sciences. 2014;5(2):1453-65.

37. Garbi MI, Saleh MS, Badri AM, et al. Antibacterial activity, phytochemical screening and cytotoxicity of Hibiscus sabdariffa (calyx). Journal of Advancement in Medicinal Plant Research. 2016;4(4):116-21.

38. Adusei S. Bioactive compounds and antioxidant evaluation of methanolic ex tract of Hibiscus sabdariffa. IPTEK the Journal for Technology and Science. 2020;31(2):139-47.

39. Alaga TO, Edema MO, Bankole MO. Phytochemical and in vitro anti-bacterial properties of Hibiscus sabdariffa I. (Roselle) juice. Journal of Medicinal Plants Research. 2014;8(7):339-44

40. Raffa D, Maggio B, Raimondi MV, et al. Recent discoveries of anticancer flavonoids. European Journal of Medicinal Chemistry. 2017;142:213-28.

41. Priyadarsini RV, Murugan RS, Maitreyi $S$, et al. The flavonoid quercetin induces cell cycle arrest and mitochondria-mediated apoptosis in human cervical cancer (HeLa) cells through p53 induction and NF-kB inhibition. European Journal of Pharmacology. 2010;649(1-3):84-91.

42. Tavsan Z, Kayali HA. Flavonoids showed anticancer effects on the ovarian cancer cells: Involvement of reactive oxygen species, apoptosis, cell cycle and invasion. Biomedicine and Pharmacotherapy. 2019;116:109004.

43. Song $X L$, Zhang YJ, Wang XF, et al. Casticin induces apoptosis and G0/G1 cell cycle arrest in gall bladder cancer cells. Cancer Cell International. 2017;17(1):110.

44. Thangaraj K, Balasubramanian B, Park S, et al. Orientin induces G0/G1 cell cycle arrest and mitochondria mediated intrinsic apoptosis in human colorectal carcinoma HT29 Cells. Biomolecules. 2019;9(9):418.

45. Ling Z, Guan H, You Z, et al. Aloperine executes antitumor effects through the induction of apoptosis and cell cycle arrest in prostate cancer in vitro and in vivo. Onco Targets and Therapy. 2018;11:2735-43.

46. Chang MY, Shieh DE, Chen CC, et al. Linalool induces cell cycle arrest and apoptosis in leukemia cells and cervical cancer cells through CDKIs. International Journal of Molecular Sciences. 2015;16(12):28169-79.

47. Komata $T$, Kanzawa $T$, Takeuchi $H$, et al. Antitumour effect of cyclin-dependent kinase inhibitors (p16 INK4A, p18 INK4C, p19 INK4D, p21 WAF1/CIP1 and p27 KIP1) on malignant glioma cells. British Journal of Cancer. 2003;88(8):1277-80.

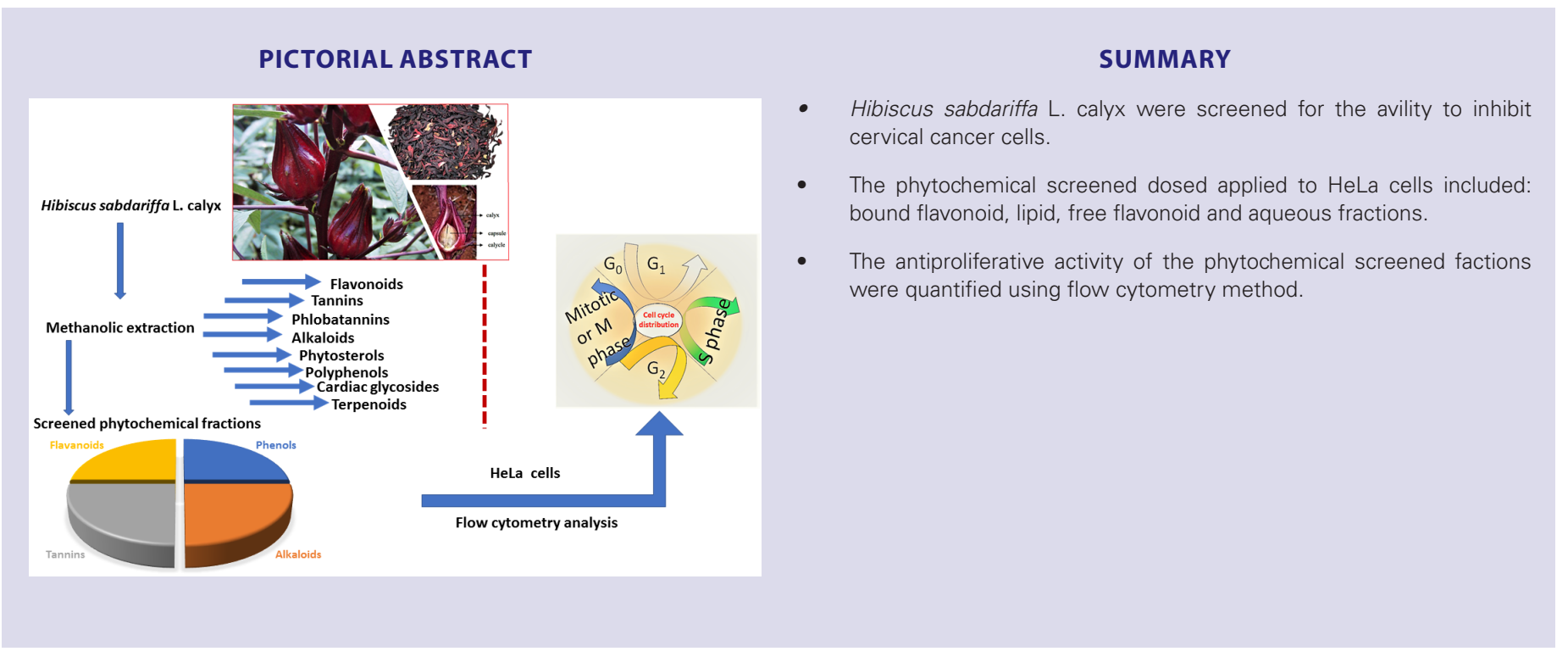




\section{ABOUT AUTHORS}

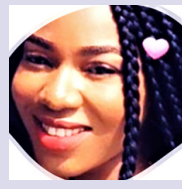

Temilola Aina holds a Bachelor's Technology degree in Biochemistry and a Master's degree in Biochemistry from the Department of Biochemistry, College of Medicine, University of Lagos, Nigeria.

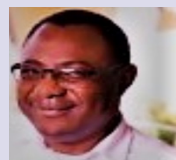

Victor Akpe is a $\mathrm{PhD}$ candidate in the School of Environment and Science at Griffith University. Victor's interest in cancer research includes among using plant extracts to build 3D nanomaterial derived scaffolds, which when combined, can be used as cell-based assays and synergistic platforms for drug discovery.

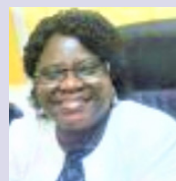

Prof Olubunmi Magbagbeola is a Professor of Biochemistry, College of Medicine, University of Lagos. Prof Magbagbeola has expertise in endocrinology and contraceptive technology, including the medicinal application of plant extracts for treating biological disorders.

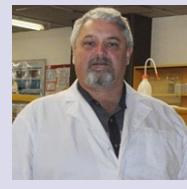

Dr. Ian Cock leads a research team in the Environmental Futures Research Institute and the School of Natural Sciences at Griffith University, Australia. His research involves bioactivity and phytochemical studies into a variety of plant species of both Australian and international origin, including Aloe vera, South Asian and South American tropical fruits, as well as Australia plants including Scaevola spinescens, Pittosporum phylliraeoides, Terminalia ferdinandiana (Kakadu plum), Australian Acacias, Syzygiums, Petalostigmas and Xanthorrhoea johnsonii (grass trees). This range of projects has resulted in nearly 250 scientific publications in a variety of peer reviewed journals. 